\title{
Effect of Content of Sulfate Groups in Seaweed Polysaccharides on Antioxidant Activity and Repair Effect of Subcellular Organelles in Injured HK-2 Cells
}

\author{
Xiao-Tao Ma, ${ }^{1}$ Xin-Yuan Sun, ${ }^{2}$ Kai Yu, ${ }^{2}$ Bao-Song Gui, ${ }^{1}$ Qin Gui, ${ }^{2}$ and Jian-Ming Ouyang ${ }^{2}$ \\ ${ }^{1}$ Department of Nephrology, The Second Hospital of Xi'an Jiaotong University, Xi'an 710004, China \\ ${ }^{2}$ Institute of Biomineralization and Lithiasis Research, Jinan University, Guangzhou 510632, China
}

Correspondence should be addressed to Bao-Song Gui; guibsdoctor@sina.com and Jian-Ming Ouyang; toyjm@jnu.edu.cn

Received 9 January 2017; Accepted 30 April 2017; Published 12 July 2017

Academic Editor: Janusz Gebicki

Copyright ( 2017 Xiao-Tao Ma et al. This is an open access article distributed under the Creative Commons Attribution License, which permits unrestricted use, distribution, and reproduction in any medium, provided the original work is properly cited.

\begin{abstract}
This study aims to investigate the repair effect of subcellular structure injuries of the HK-2 cells of four degraded seaweed polysaccharides (DSPs), namely, the degraded Porphyra yezoensis, Gracilaria lemaneiformis, Sargassum fusiform, and Undaria pinnatifida polysaccharides. The four DSPs have similar molecular weight, but with different content of sulfate groups (i.e., $17.9 \%, 13.3 \%, 8.2 \%$, and $5.5 \%$, resp.). The damaged model was established using $2.8 \mathrm{mmol} / \mathrm{L}$ oxalate to injure HK-2 cells, and $60 \mu \mathrm{g} / \mathrm{mL}$ of various DSPs was used to repair the damaged cells. With the increase of sulfate group content in DSPs, the scavenging activity of radicals and their reducing power were all improved. Four kinds of DSPs have repair effect on the subcellular organelles of damaged HK-2 cells. After being repaired by DSPs, the release amount of lactate dehydrogenase was decreased, the integrity of cell membrane and lysosome increased, the $\Delta \psi \mathrm{m}$ increased, the cell of G1 phase arrest was inhibited, the proportion of S phase increased, and cell apoptotic and necrosis rates were significantly reduced. The greater the content of sulfate group is, the stronger is the repair ability of the polysaccharide. These DSPs, particularly the polysaccharide with higher sulfate group content, may be a potential drug for the prevention and cure of kidney stones.
\end{abstract}

\section{Introduction}

Oxidative stress is one of the main factors that cause diseases [1]. High concentration of oxalate and calcium oxalate crystal can cause the oxidative damage or dysfunction of renal epithelial cells and promote crystal retention [2], resulting in an excessive production of reactive oxygen species (ROS). The ROS induces the lipid peroxidation of biological membranes by reacting with unsaturated fatty acids on the cell membrane [3], disrupts structural integrity and energy production, and even causes cell necrosis, which will accelerate the formation of kidney stone [4]. Thus, the reduction of oxidative damage of cells and the repair of the damaged cells can reduce the incidence rate of kidney stones.

Sulfated seaweed polysaccharides exhibit antioxidant activities, which are closely related to their physicochemical properties, such as molecular weight, $-\mathrm{OSO}_{3} \mathrm{H}$ content, and polyphenol content [5-8]. For example, Wang et al. [7] extracted three components from Laminaria japonica (F1, F2, and F3) with sulfate contents of $23.30 \%, 36.41 \%$, and $36.67 \%$, respectively, and their ability of scavenging superoxide anion, hydroxyl radical, chelating ability, and reducing power all decreased in the order of F3 $>$ F2 $>$ F1, which suggested that sulfate content was positively related with the bioactivities of a polysaccharide. Imbs et al. [8] studied the antioxidant activities of fucose-containing sulfated polysaccharides (FCSPs) obtained from Fucus evanescens; the results showed that the antioxidant activity of FCSPs was positively correlated with polyphenol content in FCSPs.

Moreover, sulfated seaweed polysaccharides have protective and repair effects on damaged cells caused by oxidative stress [9-13]. For instance, sulfated polysaccharides extracted from Sargassum horneri can protect RAW264.7 cells against $\mathrm{H}_{2} \mathrm{O}_{2}$-induced oxidative injury [9]. Stichopus japonicus polysaccharide (SJP) can protect PC12 from $\mathrm{Na}_{2} \mathrm{~S}_{2} \mathrm{O}_{4}$-induced 
TABLE 1: Molecular weight and content of $-\mathrm{OSO}_{3} \mathrm{H}$ and $-\mathrm{COOH}$ groups of four DSPs as well as comparison of the scavenging capacity of . $\mathrm{OH}$ and DPPH radicals.

\begin{tabular}{|c|c|c|c|c|c|}
\hline Polysaccharide type & $\begin{array}{c}\text { Mean molecular } \\
\text { weight } M / \mathrm{Da}\end{array}$ & $-\mathrm{OSO}_{3} \mathrm{H}$ content $/ \%$ & $-\mathrm{COOH}$ content/\% & $\begin{array}{l}\text { OH radical scavenging } \\
\text { capacity } \mathrm{IC}_{50} / \mathrm{mg} / \mathrm{mL}\end{array}$ & $\begin{array}{l}\text { DPPH radical scavenging } \\
\text { capacity } \mathrm{IC}_{50} / \mathrm{mg} / \mathrm{mL}\end{array}$ \\
\hline DPY-1 & 4020 & 17.9 & 1.7 & 2.75 & 1.82 \\
\hline DGL-2 & 3343 & 13.3 & 1.0 & 7.21 & 8.24 \\
\hline DSF-3 & 3828 & 8.2 & 1.3 & 8.33 & 9.68 \\
\hline DUP-4 & 3635 & 5.5 & 1.2 & 9.21 & 14.6 \\
\hline Vc control & - & - & - & 1.57 & 0.91 \\
\hline
\end{tabular}

DPY-1: degraded Porphyra yezoensis polysaccharide; DGL-2: degraded Gracilaria lemaneiformis polysaccharide; DSF-3: degraded Sargassum fusiform polysaccharide; DUP-4: degraded Undaria pinnatifida polysaccharide; Vc: ascorbic acid.

oxidative damage [10]. The cell viability of the SJP protective group $(64.7 \pm 1.64 \%)$ was higher than the unprotected group $(46.8 \pm 1.4 \%)$; SJP can significantly decrease MDA level and increase SOD activity and mitochondrial membrane potential. Thevanayagam et al. [12] found that the repair effect of seaweed polysaccharide on the UV-induced normal human keratinocyte (HaCaT) cell damage gradually increased with the increasing sulfation degree of polysaccharide. Wang et al. [13] reported two sulfated Cyclocarya paliurus polysaccharides $\left(\mathrm{S}-\mathrm{CP}_{1-4}\right.$ and $\left.\mathrm{S}-\mathrm{CP}_{1-8}\right)$ with a substitution degree of $0.42 \pm 0.04$ and $0.12 \pm 0.02$, respectively, and found that they had better protective effect on RAW264.7 cells against $\mathrm{H}_{2} \mathrm{O}_{2}$-induced oxidative stress as compared with the native polysaccharide. In addition, their protective effect was correlated with their sulfation degree.

In the previous report [14], four seaweed polysaccharides, namely, Porphyra yezoensis polysaccharide (DPY-1), Gracilaria lemaneiformis polysaccharide (DGL-2), Sargassum fusiform polysaccharide (DSF-3), and Undaria pinnatifida polysaccharide (DUP-4), were degraded by controlling the concentration of hydrogen peroxide and using four kinds of sulfation degree of polysaccharide products with similar molecular weight of about $3700 \mathrm{Da}$, but with different content of sulfate group $\left(-\mathrm{OSO}_{3} \mathrm{H}\right)$ consisting $17.9 \%, 13.3 \%$, $8.2 \%$, and $5.5 \%$, respectively. The structure of these polysaccharides was studied, showing that the four seaweed polysaccharides are mainly composed of galactose and/or fucose. DPY-1 and DGL-2 are primarily composed of galactose; the contents of which reach to 92.0 and 95.8, respectively. Meanwhile, DSF-3 and DUP-4 mostly contained galactose and fucose [15-18]. Furthermore, we found that these polysaccharides were not toxic to human renal proximal tubular epithelial cells (HK-2) in the concentration range of $0-100 \mu \mathrm{g} / \mathrm{mL}$. Additionally, the repair effect of polysaccharides was determined using cell viability test by CCK- 8 assay and cell morphology observation by hematoxylin-eosin staining, respectively. Results showed that the degraded polysaccharide had better repair effect than the original polysaccharide.

The functions of subcellular organelles changed after the cells were damaged. To further study the effect of $-\mathrm{OSO}_{3} \mathrm{H}$ content on the repair effect of seaweed polysaccharide, the repair effect of the above four degraded seaweed polysaccharides (DSPs) with different $-\mathrm{OSO}_{3} \mathrm{H}$ content on subcellular organelles of damaged $\mathrm{HK}-2$ cells was investigated. We expect to explore the repair mechanism of DSPs at cellular and molecular levels, provide scientific basis for the prevention of kidney stone, and develop new antistone drugs.

\section{Experiments}

2.1. Reagents and Apparatus. Human kidney proximal tubular epithelial (HK-2) cells were purchased from Shanghai Cell Bank, Chinese Academy of Sciences (Shanghai, China). Dulbecco's modified Eagle's medium (DMEM) and fetal bovine serum were purchased from HyClone Biochemical Products Co. Ltd. (UT, USA). Cell culture plates of 6, 12, and 96-well were purchased from Wuxi Nest Bio-Tech Co. Ltd. (Wuxi, China). Trypsin, penicillin and streptomycin, 5,5',6,6'-tetrachloro-1,1',3,3'-tetraethylbenzimi-dazolylcarbocyanine iodide (JC-1), propidium iodide (PI), annexin VFITC/PI, acridine orange (AO), and lactate dehydrogenase $(\mathrm{LDH})$ kit were all purchased from Shanghai Beyotime Bio-Tech Co. Ltd.(Shanghai, China). Ethyl alcohol, oxalate, and other chemical reagents were all analytically pure and purchased from Guangzhou Chemical Reagent Factory of China (Guangzhou, China).

Porphyra yezoensis polysaccharide, Gracilaria lemaneiformis polysaccharide, Sargassum fusiform polysaccharide, and Undaria pinnatifida polysaccharides were produced by Beijing Newprobe Instrument Co. Ltd. Their degraded products with similar molecular weight (about $3700 \mathrm{Da}$ ), named as DPY-1, DGL-2, DSF-3, and DUP-4, were obtained by controlling the degradation condition (such as $\mathrm{H}_{2} \mathrm{O}_{2}$ concentration, degraded temperature, and degraded time) according to previous paper [14]. The contents of sulfate group and carboxyl group were shown in Table 1. The possible content of polyphenols mixed in the four different polysaccharides was determined by Folin-Ciocalteu method using gallic acid as a standard [19]. The results showed that the four polysaccharides do not contain polyphenols. Thus, the effect of polyphenol on the antioxidant activity of polysaccharides can be excluded.

The apparatus included enzyme mark instrument (Safire, Tecan, Switzerland), flow cytometry (FACS Aria, American BD Company), fluorescence microscope (Leica DMIRE2, Germany), optical microscope (Olympus, CKX41, Japan), and UV-Vis spectrophotometer (Cary 500, Varian Company, USA). 


\subsection{Antioxidant Activity Assays of Polysaccharides}

2.2.1. Hydroxyl Radical (.OH) Scavenging Activity of Polysaccharides. The $\cdot \mathrm{OH}$ scavenging ability of polysaccharide in vitro was detected by $\mathrm{H}_{2} \mathrm{O}_{2} / \mathrm{Fe}$ system method [20]. The reaction mixture that contained different concentrations of polysaccharides $(0.15-3.0 \mathrm{mg} / \mathrm{mL}, 1 \mathrm{~mL})$ was incubated with phenanthroline $(2.5 \mathrm{mmol} / \mathrm{L}, 1 \mathrm{~mL})$, ferrous sulfate $(2.5 \mathrm{mmol} / \mathrm{L}, 1 \mathrm{~mL})$, and hydrogen peroxide $(20 \mathrm{mmol} / \mathrm{L}, 1 \mathrm{~mL})$ in phosphate buffer $(20 \mathrm{mmol} / \mathrm{L}, 1 \mathrm{~mL}$, $\mathrm{pH} 7.4$ ) for $90 \mathrm{~min}$ at $37^{\circ} \mathrm{C}$. The absorbance measured at $536 \mathrm{~nm}$ was designated $A_{1}$. The absorbance when hydrogen peroxide $\left(\mathrm{H}_{2} \mathrm{O}_{2}\right)$ was replaced with distilled water and polysaccharide solution was $A_{2}$ and $A_{3}$, respectively. The ascorbic acid ( $\mathrm{Vc}$ ) was used as positive control group. The ability to scavenge hydroxyl radicals was calculated using the following equation:

$$
\text { Scavenging effect }(\%)=\frac{\left(A_{3}-A_{1}\right)}{\left(A_{2}-A_{1}\right)} \times 100 \% \text {. }
$$

2.2.2. DPPH Radical Scavenging Activity of Polysaccharides. The DPPH radical scavenging activity was carried out according to Wang et al. [21] with minor modification. $\mathrm{DPPH}$ solution was prepared to be $0.4 \mathrm{mmol} / \mathrm{L}$ using dehydrated alcohol, each polysaccharide solution $(3 \mathrm{~mL})$ was mixed with DPPH solution $(0.4 \mathrm{mmol} / \mathrm{L}, 1 \mathrm{~mL})$ in a test tube, and final concentration of polysaccharide and DPPH solution was $0.15,0.5,0.8,1.0,2.0,3.0 \mathrm{mg} / \mathrm{mL}$, and $0.1 \mathrm{mmol} / \mathrm{L}$, respectively. After the mixture was left to stand for $30 \mathrm{~min}$ at $25^{\circ} \mathrm{C}$ in the dark, the absorbance was measured at $517 \mathrm{~nm}$. The ascorbic acid (Vc) was used as positive control group. The ability to scavenge DPPH radicals was calculated using the following equation:

$$
\text { Scavenging effect }(\%)=\left[1-\frac{\left(A_{2}-A_{1}\right)}{A_{0}}\right] \times 100 \% \text {, }
$$

where $A_{2}$ was the absorbance of $3 \mathrm{~mL}$ sample mixed with $1 \mathrm{~mL}$ DPPH solution; $A_{1}$ was the absorbance of $3 \mathrm{~mL}$ sample mixed with $1 \mathrm{~mL}$ blank solvent (dehydrated alcohol); and $A_{0}$ was $1 \mathrm{~mL}$ DPPH solution mixed with $3 \mathrm{~mL}$ blank solvent.

$\mathrm{DPPH}$ is stable in the form of nitrogen free radical, and the solution is purple. When antioxidant was added, the antioxidant donated an electron or hydrogen to $\mathrm{DPPH}$ and formed a stable DPPH-H molecule and purpleness of the solution faded. Therefore, the DPPH free radical scavenging rate can be calculated through the change of absorbance.

2.2.3. ABTS Radical Scavenging Activity of Polysaccharides. The ABTS radical scavenging activity of polysaccharides was performed according to [22] with slight modification. $7 \mathrm{mmol} / \mathrm{L}$ ABTS solution was mixed with $2.45 \mathrm{mmol} / \mathrm{L}$ potassium persulfate aqueous solution, and then, the mixture was incubated in the dark at room temperature for $12-16 \mathrm{~h}$. Then, $3.0 \mathrm{~mL}$ mixture solution was added to $1 \mathrm{~mL}$ of various polysaccharide solutions $(0.15-3 \mathrm{mg} / \mathrm{mL})$ in test tube. After reacting for $6 \mathrm{~min}$ at room temperature, the absorbance was measured at $734 \mathrm{~nm}$.

$$
\text { Scavenging effect }(\%)=\left[1-\frac{\left(A_{1}-A_{2}\right)}{A_{0}}\right] \times 100 \%,
$$

where $A_{0}$ is the control group without polysaccharide; $A_{1}$ is the experiment group; and $A_{2}$ is the blank group without reagents (the absorbance of polysaccharide solution $\left(A_{2}\right)$ was 0 ).

2.2.4. Reducing Power of Polysaccharides. The reducing power of polysaccharides was determined by referring to [23] with some modifications. 2.5 milliliter of polysaccharide samples in different concentrations $(0.15-3.0 \mathrm{mg} / \mathrm{mL})$ was mixed with $2.5 \mathrm{~mL}$ phosphate buffer (PBS, $\mathrm{pH}=6.6$ ) and $2.5 \mathrm{~mL}$ potassium ferricyanide $(1.0 \%, w / v)$. The mixture was incubated at $50^{\circ} \mathrm{C}$ for $30 \mathrm{~min}$ and cooled to room temperature. 2.5 milliliter of trichloroacetic acid $(10 \%, w / v)$ was added to the mixture which was then centrifuged for $10 \mathrm{~min}$ at $3000 \mathrm{r} / \mathrm{min}$. The supernatant $(2.5 \mathrm{~mL})$ was mixed with $0.5 \mathrm{~mL} \mathrm{FeCl}_{3} \cdot 6 \mathrm{H}_{2} \mathrm{O}(0.1 \%, w / v)$ solution and $5.0 \mathrm{~mL}$ distilled water. The mixture was fully mixed and stood for $10 \mathrm{~min}$. The absorbance was measured at $700 \mathrm{~nm}$. The ascorbic acid $\left(\mathrm{V}_{\mathrm{C}}\right)$ was used as a positive control group and for comparison.

Antioxidants can donate an electron which reduce ferric of potassium ferricyanide $\left(\mathrm{K}_{4}\left[\mathrm{Fe}(\mathrm{CN})_{6}\right]\right)$ to ferrous iron, and then, ferrous iron reacted with $\mathrm{FeCl}_{3} \cdot 6 \mathrm{H}_{2} \mathrm{O}$ to form $\mathrm{Fe}_{4}\left[\mathrm{Fe}_{6}(\mathrm{CN})_{3}\right]_{3}$ with maximum absorbance value at $700 \mathrm{~nm}$. Therefore, the absorbance measured at $700 \mathrm{~nm}$ can indirectly reflect reducing power. A higher absorbance indicated that stronger reducing power.

\subsection{Cell Repair Assays of Polysaccharides with Different Content of Sulfate Groups}

2.3.1. Cell Culture. HK-2 cells were cultured in a DMEM culture medium containing $10 \%$ fetal bovine serum and $100 \mathrm{U} / \mathrm{mL}$ penicillin- $100 \mu \mathrm{g} / \mathrm{mL}$ streptomycin antibiotics with $\mathrm{pH} 7.4$ at $37^{\circ} \mathrm{C}$ in a $5 \% \mathrm{CO}_{2}$ humidified environment. Upon reaching $80 \%-90 \%$ confluent monolayer, cells were blown gently after trypsin digestion to form cell suspension for the following cell experiment.

2.3.2. Lactate Dehydrogenase (LDH) Release Assay. Cell suspension with a cell concentration of $1 \times 10^{5}$ cells $/ \mathrm{mL}$ was inoculated per well in 96-well plates and incubated in DMEM culture medium for $24 \mathrm{~h}$. The cells were divided into five groups: (1) cell-free culture medium wells (control wells of background); (2) control wells without drug treatment (sample control wells); (3) cells without drug treatment for the subsequent cleavage of the wells (sample maximum enzyme activity control wells); (4) injury group, the serum-free medium containing $2.8 \mathrm{mmol} / \mathrm{L}$ oxalate was added and incubated for $3 \mathrm{~h}$; (5) repair group, the serum-free medium containing $60 \mu \mathrm{g} / \mathrm{mL}$ DPY-1, DGL-2, DSF-3, and DUP-4 polysaccharide was added to repair the damaged cells and incubated for $12 \mathrm{~h}$. After the repair was completed, enzyme mark instrument was used to detect the 
OD value of each group according to LDH kit method. The results were calculated as LDH release amount (\%) = (the absorbance of sample - treated group - the absorbance of sample control group)/(the absorbance of sample maximum enzyme activity - the absorbance of sample control group) $\times 100$.

2.3.3. Measurement of Mitochondria Membrane Potential $(\Delta \Psi m)$. Cell suspension with a cell concentration of $1 \times 10^{5}$ cells $/ \mathrm{mL}$ was inoculated per well in 6-well plates and incubated as mentioned above. The cells were divided into three groups: (1) control group, (2) injury group, and (3) repair group; the repaired time was $12 \mathrm{~h}$. After the repair was completed, the cells were collected and centrifuged at $1000 \mathrm{rpm} /$ min for $5 \mathrm{~min}$. After that, the supernatant was removed by suction and cells were rinsed twice with PBS. The $\Delta \Psi \mathrm{m}$ was detected according to JC-1 kit. Then, the cells were stained with $200 \mu \mathrm{L}$ JC-1 dye, thoroughly mixed, and incubated in darkness at $37^{\circ} \mathrm{C}$ for $15 \mathrm{~min}$. After treatment, the cells were detected by flow cytometry.

2.3.4. Cell Cycle Assay [24]. Cell suspension with a cell concentration of $1 \times 10^{5}$ cells $/ \mathrm{mL}$ was inoculated per well in 6-well plates and incubated as mentioned above. After being repaired for $12 \mathrm{~h}$, the cells were collected with trypsin digestion. The collected cells were washed twice with PBS and centrifugation (1000 rpm, $5 \mathrm{~min}$ ), then fixed using $70 \%$ ethanol for $12 \mathrm{~h}$ at $4^{\circ} \mathrm{C}$. Ethanol was removed by centrifugation (2000 rpm, $5 \mathrm{~min}$ ), and the cells were washed twice with PBS. Cells were then resuspended in $200 \mu \mathrm{L}$ propidium iodide and kept at $37^{\circ} \mathrm{C}$ for $15 \mathrm{~min}$. The cell cycle was analyzed by measuring the amount of PI-labeled DNA in fixed cells by the flow cytometer.

2.3.5. Lysosomal Integrity Assay [25]. For fluorescence qualitative observation by fluorescence microscope, the cell suspension with a cell concentration of $1 \times 10^{5}$ cells $/ \mathrm{mL}$ was inoculated to subconfluence in 12-well plates with coverslips for $24 \mathrm{~h}$. The cells were washed twice with PBS and then loaded with $5 \mu \mathrm{g} / \mathrm{mL}$ AO in DMEM for $15 \mathrm{~min}$. The cells were divided into three groups as mentioned above. After being repaired for $12 \mathrm{~h}$, the cells were rinsed three times with $\mathrm{PBS}$ and the distribution of $\mathrm{AO}$ in cells was observed under fluorescence microscope.

For fluorescence quantitative detection by microplate reader, cells $\left(1.0 \times 10^{5}\right.$ cells $\left./ \mathrm{mL}\right)$ were cultured in a 96-well plate $(100 \mu \mathrm{L} /$ well $)$ and were stained with $\mathrm{AO}$; the cells were washed with PBS before fluorescence measurements with excitation at $485 \mathrm{~nm}$ and emission at 530 (green cytoplasmic AO) and $620 \mathrm{~nm}$ (red lysosomal AO). Normal lysosomal integrity $=$ (total red fluorescence intensity of normal lysosome)/(total green fluorescence intensity of normal lysosome). Lysosomal integrity $=$ (total red fluorescence intensity) $/[$ (total green fluorescence intensity) $\times$ (normal lysosomal integrity)].

2.3.6. Cell Apoptosis Assay [26]. Cell suspension with a cell concentration of $1 \times 10^{5}$ cells $/ \mathrm{mL}$ was inoculated per well in 6 -well plates and incubated for $24 \mathrm{~h}$. As above, the cells were divided into three groups. After reaching the repair time of
$12 \mathrm{~h}$ and doing corresponding treatment, the cells were collected and centrifuged at $1000 \mathrm{rpm} / \mathrm{min}$ for $5 \mathrm{~min}$. The cells were resuspended in $200 \mu \mathrm{L}$ binding buffer. Afterward, $5 \mu \mathrm{L}$ annexin V-FITC was added and then incubated in darkness at room temperature for $10 \mathrm{~min}$. The cells were again resuspended in $200 \mu \mathrm{L}$ binding buffer and stained with $5 \mu \mathrm{L}$ PI. The prepared cells were then analyzed using a flow cytometer.

2.4. Statistical Analysis. Experimental data were expressed by mean \pm standard deviation $(x \pm S D)$. The experimental results were analyzed statistically using SPSS 13.0 software. The differences of means between the experimental groups and the control group were analyzed by Tukey. If $p<0.05$, there was significant difference; if $p<0.01$, the difference was extremely significant; if $p>0.05$, there was no significant difference.

\section{Results and Discussion}

\subsection{Antioxidant Activity of Polysaccharides with Different Sulfate Group Content}

3.1.1. Hydroxyl Radical (.OH) Scavenging Capacity. In biological ROS, $\cdot \mathrm{OH}$ is the most active radical, which can easily cross cell membranes, readily react with most biomolecules (including carbohydrates, proteins, lipids, and DNA in cells), and cause tissue damage or cell death, eventually leading to many diseases $[27,28]$.

As shown in Figure 1(a), four DSPs showed the scavenging capacity of $\cdot \mathrm{OH}$ in a concentration-dependent manner. Results revealed that polysaccharides with higher concentration exerted stronger scavenging capacity. Also, the polysaccharide with higher sulfate group content has stronger $\cdot \mathrm{OH}$ scavenging capacity at the same concentration. For example, at the concentration of $3.0 \mathrm{mg} / \mathrm{mL}$ of a polysaccharide, the $\cdot \mathrm{OH}$ scavenging rate was DPY-1 (40.7\%) > DGL-2 $(23.8 \%)>$ DSF-3 $(20.8 \%)>$ DUP-4 (17.1\%), which was in accordance with the sequence of sulfate group content of four DSPs $(17.9 \%, 13.3 \%, 8.2 \%$, and $5.5 \%)$. The $\mathrm{IC}_{50}$ values of the four DSPs and Vc were 2.75, 7.21, 8.33, 9.21 , and $1.57 \mathrm{mg} / \mathrm{mL}$, respectively (Table 1 ).

3.1.2. DPPH Radical Scavenging Capacity. The result of DPPH radical scavenging of four DSPs is shown in Figure 1(b). All the polysaccharides exhibited the DPPH radical scavenging capacity in a concentration-dependent manner, and a higher concentration of polysaccharide indicated a higher radical scavenging rate. For the different DSPs, the higher sulfate group content of polysaccharide indicated a stronger DPPH free radical scavenging capacity at the same concentration. For all the polysaccharides with similar molecular weight, the active $-\mathrm{OSO}_{3} \mathrm{H}$ group is the main factor affecting the free radical scavenging capacity of a polysaccharide. The $\mathrm{IC}_{50}$ values of scavenging DPPH free radical of the four DSPs and $\mathrm{Vc}_{\mathrm{c}}$ were 14.6, 9.68, 8.24, 1.82, and $0.91 \mathrm{mg} / \mathrm{mL}$, respectively (Table 1 ).

3.1.3. ABTS Radical Scavenging Capacity. ABTS assay is an important method used to measure the antioxidant capacity of antioxidants. The result of ABTS radical scavenging of 


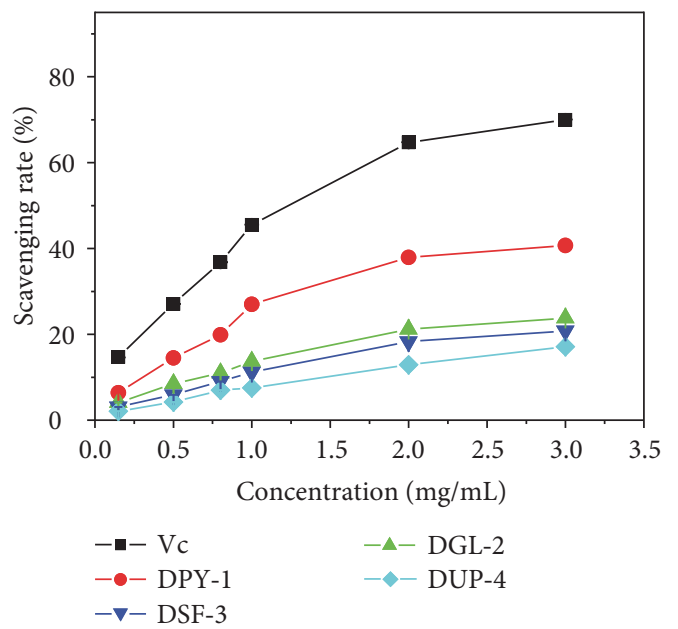

(a)

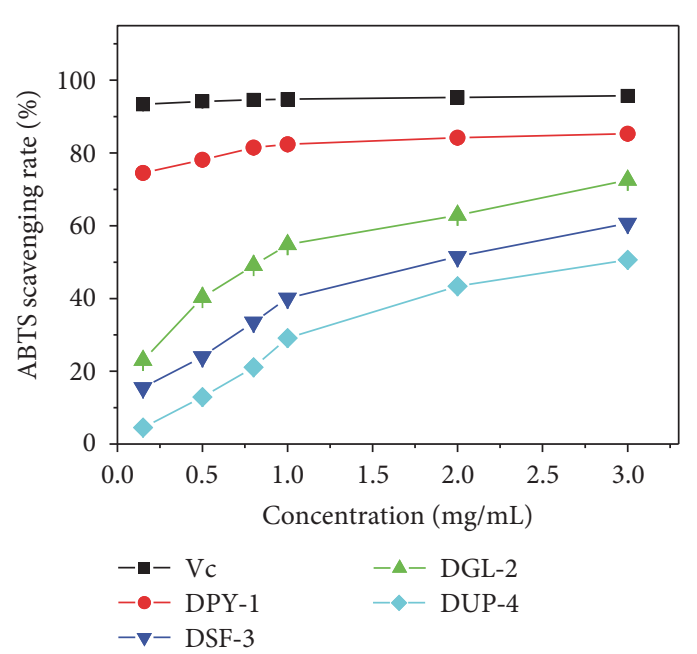

(c)

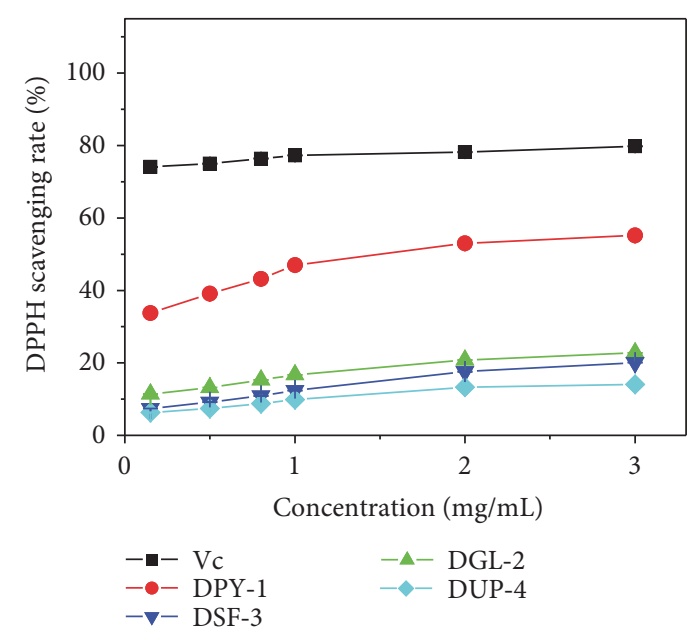

(b)

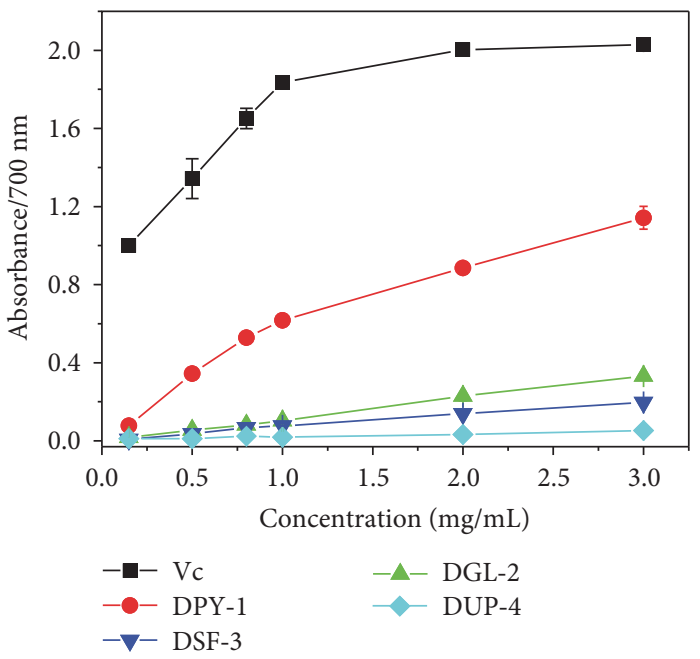

(d)

FIGURE 1: Comparison of antioxidant activity of four DSPs with different $-\mathrm{OSO}_{3} \mathrm{H}$ content: (a) hydroxyl radical scavenging rate; (b) DPPH radical scavenging rate; (c) ABTS radical scavenging rate; and (d) reducing power.

the four DSPs is shown in Figure 1(c). All the polysaccharides exhibited the ABTS radical scavenging capacity in concentration-dependent manner, and the higher concentration of polysaccharide indicated a higher radical scavenging rate. For the different DSPs, the higher sulfate group content of polysaccharide indicated a stronger ABTS free radical scavenging capacity at the same concentration. For all the polysaccharides with similar molecular weight, the active $-\mathrm{OSO}_{3} \mathrm{H}$ group is the main factor affecting the ABTS radical scavenging capacity of a polysaccharide.

3.1.4. Reducing Power of Polysaccharide. The reducing power of a polysaccharide has a direct, positive correlation with antioxidant capacity [29]. Natural antioxidants can terminate free radical chain reaction by their capacity to donate an electron or hydrogen atom to free radicals. Thus, the reducing capacity of antioxidant may serve as a significant indicator of its potential antioxidant activity [30].

As shown in Figure 1(d), the absorbance measured at $700 \mathrm{~nm}$ increased with the increasing concentration of a polysaccharide, suggesting that the reducing power was strengthened in a concentration-dependent manner. For the different polysaccharides, the absorbance, that is, the reducing power of polysaccharide, increased with the increasing content of sulfate groups.

Antioxidant activity of polysaccharides is related to several structural characteristics, such as branch chain, glycosidic linkage, steric conformation, and monosaccharide composition; of which, the influences of molecular weight $[31,32]$ and acid group content $[33,34]$ are the most noticeable. For polysaccharides with similar molecular weight (approximately $3700 \mathrm{Da}$ ) in our study, the acid group content is the most critical factor that influences the antioxidant activity of polysaccharides. Comprehensively concluding the four antioxidant results in Figure 1, the antioxidant activity of DSPs has the following change rules:

(1) Acidic groups in polysaccharide ( such as $-\mathrm{OSO}_{3} \mathrm{H}$ ) can be complex with transition metal ions (such as $\mathrm{Fe}^{3+}$ ) that are necessary in catalyzing the free radical 


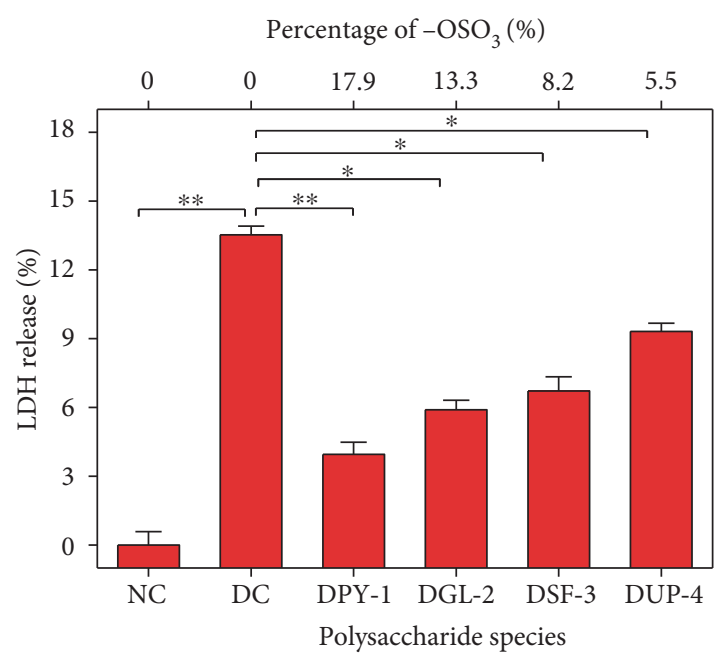

Figure 2: LDH release amount of the damaged HK-2 cells after exposure to four DSPs with different $-\mathrm{OSO}_{3} \mathrm{H}$ content. The concentration of oxalate to injury $\mathrm{HK}-2$ cells: $2.8 \mathrm{mmol} / \mathrm{L}$; injury time: $3 \mathrm{~h}$; DSP concentration: $60 \mu \mathrm{g} / \mathrm{mL}$; repaired time: $12 \mathrm{~h}$. NC: normal control; DC: damaged control. $* *$ indicates $p<0.01$; * indicates $p<0.05$.

chain reaction to stop the initiation of the free radical chain reaction and avoid the generation of radical ions. In addition, the sulfate group content is positively related to the antioxidant activity of DSPs. The electron-withdrawing sulfate groups of a polysaccharide can activate the hydrogen atom of sugar residue through field and inductive effects $[13,20]$ and donate hydrogen atom or an electron to a radical, which result in the termination of the radical chain reaction.

(2) All the polysaccharides exhibited antioxidant activities in a concentration-dependent manner.

3.2. Repair Effect of Polysaccharides on Cell Membrane. LDH is a stable enzyme of the cytoplasm that is released extracellularly once the cell membrane ruptures. Thus, LDH is considered a marker of cell membrane integrity [35].

The change of LDH release amount of the damaged HK-2 cells after being repaired by the four DSPs is shown in Figure 2. Compared with the damaged cells, LDH release amount of all the repair groups reduced in different degrees, and the reduced amount was positively correlated with the content of $-\mathrm{OSO}_{3} \mathrm{H}$ groups in polysaccharides. For example, after being repaired by DPY-1 with the highest content of $-\mathrm{OSO}_{3} \mathrm{H}(17.9 \%)$, the $\mathrm{LDH}$ release amount of the damaged HK-2 cells was the smallest (3.96\%) as compared with $13.3 \%$ from the damaged group. The $\mathrm{LDH}$ release amount of the other three repaired groups was $5.90 \%$ to $9.31 \%$. This finding suggested that DSPs with higher content of $-\mathrm{OSO}_{3} \mathrm{H}$ groups had better repair effect on the cell membrane of damaged HK-2 cells.

Numerous studies have reported the repair effect of polysaccharides on injured cell membranes. Hu et al. [36] studied the therapeutic effect of Inonotus obliquus polysaccharide (IOP) on the diethyldithiocarbamate- (DDC-) induced pancreatic acinar atrophy and chronic pancreatitis (CP) in mice. They found that the LDH release level (580 U/ L) after treatment with IOP was significantly lower than the DDC-damaged group $(880 \mathrm{U} / \mathrm{L})$. Wen et al. [9] studied the protective effect of SHS against the $\mathrm{H}_{2} \mathrm{O}_{2}$-induced oxidative damage of RAW264.7 cell; the $\mathrm{LDH}$ release amount (82, 84, $105 \mathrm{U} / \mathrm{L})$ was significantly reduced compared with the damaged group $(145 \mathrm{U} / \mathrm{L})$ after pretreated by $\mathrm{SHS}_{c}$, $\mathrm{SHS}_{1}$, and $\mathrm{SHS}_{0.5}$ polysaccharides, which had $4.95 \%$, $4.48 \%$, and $2.95 \%$ of $-\mathrm{OSO}_{3} \mathrm{H}$ content, respectively. The $\mathrm{LDH}$ release amount was smallest after the damaged HK-2 cells were repaired by $\mathrm{SHS}_{c}$, the polysaccharide that had the highest $-\mathrm{OSO}_{3} \mathrm{H}$ content.

3.3. Repair Effect of Polysaccharides on Mitochondria. A symbolic event in early apoptosis is the decrease in mitochondrial membrane potential $(\Delta \Psi \mathrm{m})$. JC-1 differentially labels mitochondria with high and low $\Delta \Psi \mathrm{m}$ by forming J-aggregates or monomers that emit orange-red or green light, respectively [37]. The $\Delta \Psi \mathrm{m}$ and concentration of J-aggregates were high in the mitochondria of living cells. From the degree that JC-1 changes from red to green fluorescence, the reduced amount of $\Delta \Psi \mathrm{m}$ can be detected.

The $\Delta \Psi \mathrm{m}$ of $\mathrm{HK}-2$ cell at different states is shown in Figure 3. The proportion of green fluorescence in the mitochondria of normal HK-2 cell was very low (1.3\%) and obviously increased after the cell was damaged by oxalate $(25.5 \%)$, which suggested that the $\Delta \Psi \mathrm{m}$ decreased obviously. However, after the damaged cells were repaired by different polysaccharides, green fluorescence reduced with different degrees, and the reduced degree was positively correlated with the $-\mathrm{OSO}_{3} \mathrm{H}$ content of each polysaccharide. That is, the higher the $-\mathrm{OSO}_{3} \mathrm{H}$ content of a polysaccharide, the lesser green fluorescence and the higher repair degree of the $\Delta \Psi \mathrm{m}$ become. In degraded DPY-1, which had the highest content of $-\mathrm{OSO}_{3} \mathrm{H}$ (17.9\%) repaired group, the proportion of green fluorescence was lowest (3.6\%).

Polysaccharides can protect the intracellular mitochondria from oxidative damage. Cui et al. [38] studied the protective effect of sulfated polysaccharide (such as SJP) against 6-OHDA-induced SH-SY5Y cell death and found that the $\Delta \Psi \mathrm{m}$ of SJP pretreatment group (79\%) was higher than 6-OHDA damaged group (56\%), suggesting that SJP had certain protective effect on 6-OHDA-induced SH-SY5Y cell damage. Li et al. [39] examined the endothelial cell death mode caused by high glucose-induced ROS and suggested that Ganoderma atrum polysaccharide (PSG-1) had protective effect on the $\Delta \Psi \mathrm{m}$. The $\Delta \Psi \mathrm{m}(36.26 \%)$ of high glucosetreated group was obviously lower than the cell of the control group $(80.44 \%)$, but the $\Delta \Psi \mathrm{m}$ increased $(60.03 \%)$ after the cells were pretreated by PSG-1.

After the mitochondria were damaged, $\Delta \Psi \mathrm{m}$ reduced and cytochrome $\mathrm{c}$ was released from the mitochondria to cytosol, which caused cell apoptosis [40]. Geng et al. [41] studied the effect of SMP1 on $\mathrm{H}_{2} \mathrm{O}_{2}$-induced cardiac muscle cell apoptosis after the cells were treated with $\mathrm{H}_{2} \mathrm{O}_{2}$ for 


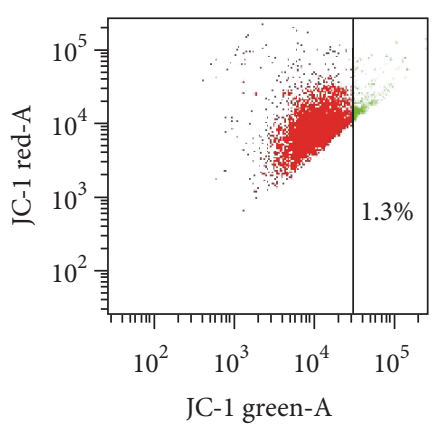

(A)

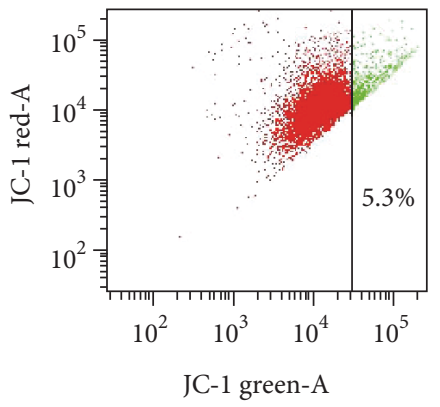

(D)

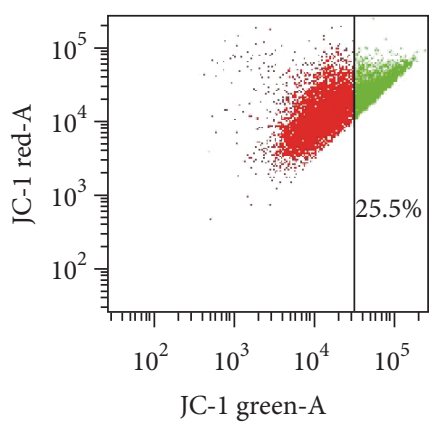

(B)

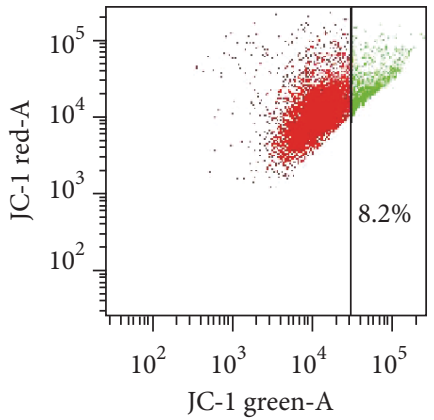

(E)

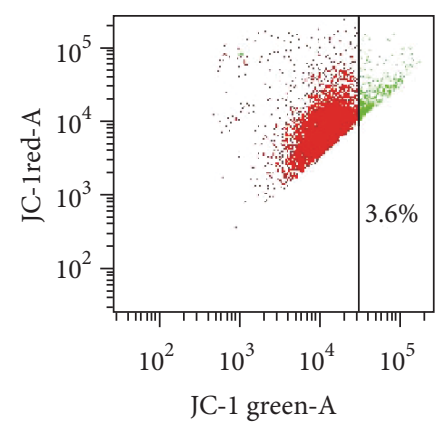

(C)

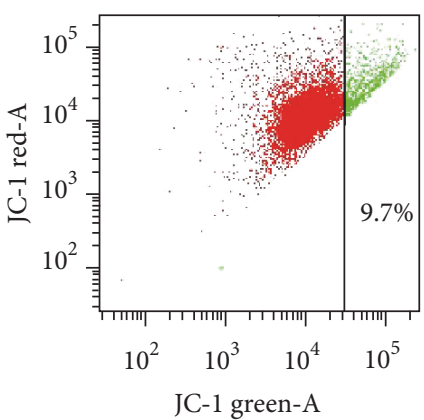

(F)

(a)

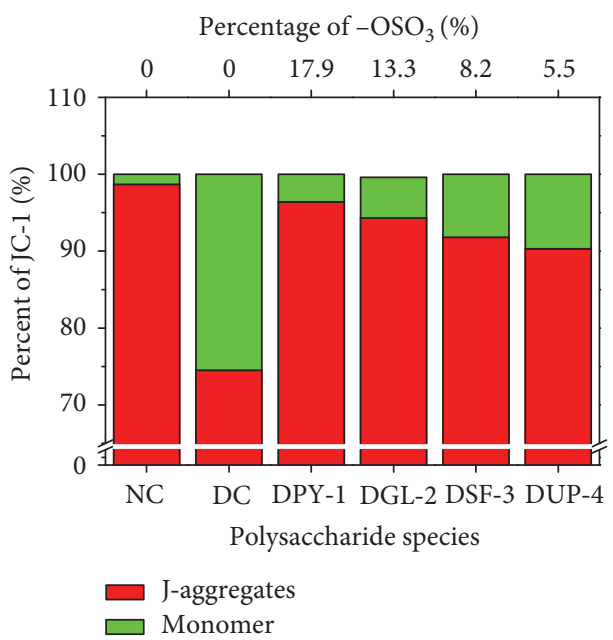

(b)

FIgURE 3: Mitochondrial membrane potential change after the damaged $\mathrm{HK}-2$ cells were repaired by four $\mathrm{DSPs}_{\text {with }}$ different $-\mathrm{OSO}_{3} \mathrm{H}$ content. (a) Dot plots of $\Delta \psi \mathrm{m}$ change; (b) the aggregated degree of JC-1. JC-1 monomers represented the reduced $\Delta \psi \mathrm{m}$. (A) normal control; (B) damaged control; (C) DPY-1; (D) DGL-2; (E) DSF-3; (F) DUP-4. DSP concentration: $60 \mu \mathrm{g} / \mathrm{mL}$; the damage concentration of oxalate: $2.8 \mathrm{mmol} / \mathrm{L}$; injury time: $3 \mathrm{~h}$; repaired time: $12 \mathrm{~h}$.

$24 \mathrm{~h}$. They found that the amount of cytochrome $\mathrm{c}$ in the mitochondria was significantly reduced, whereas the amount of cytochrome $\mathrm{c}$ released into the cytosol was significantly increased. They also found that the downregulation of Bcl-2 and upregulation of Bax expression was contrary to the results in SMP1 pretreatment group. Moreover, antiapoptotic Bcl-2 protein can inhibit cell apoptosis by preventing the release of cytochrome $c$ from the mitochondria, whereas proapoptotic Bax protein can cause the release of cytochrome $\mathrm{c}$ into the cytosol by inducing the permeabilization of the mitochondrial membrane [42].

3.4. Repair Effect of Polysaccharides on Cell Cycle. The combination of PI with double-stranded DNA can produce fluorescence, and the DNA content and distribution can be detected by flow cytometry; hence, the cell cycle can be analyzed. The cell cycle changes of each group are shown in Figure 4 . The cell number of S phase (40\%) was significantly reduced than 


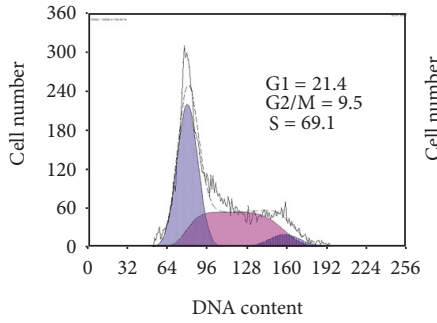

(A)

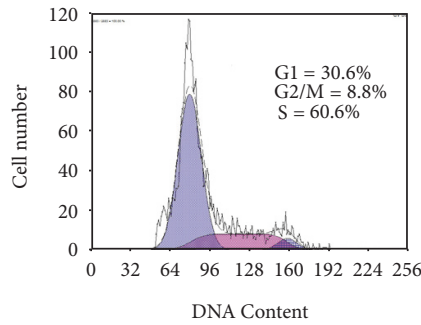

(D)

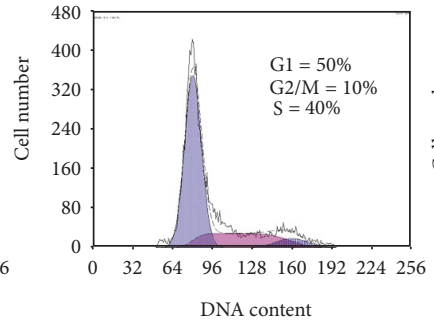

(B)

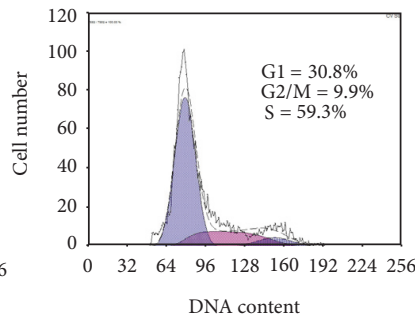

(E)

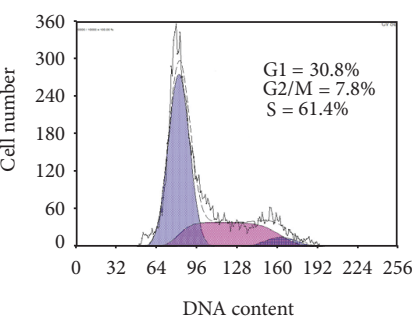

(C)

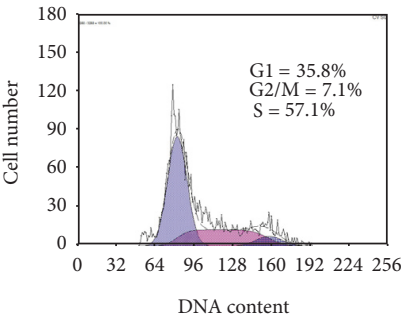

(F)

(a)

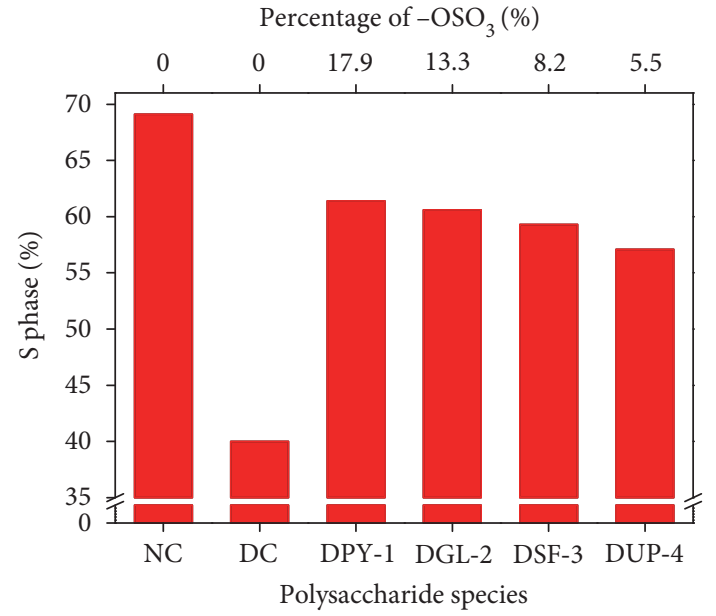

(b)

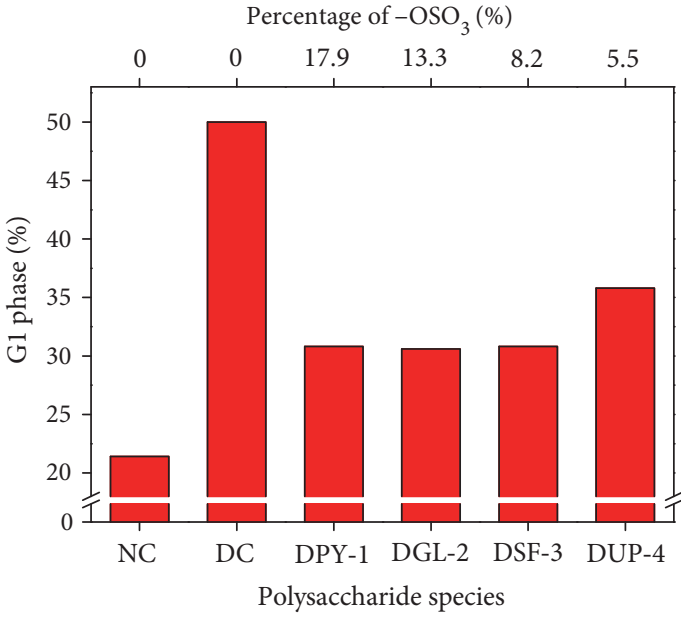

(c)

FIGURE 4: Cell cycle change of the damaged HK-2 cells after repair by four DSPs with different $-\mathrm{OSO}_{3} \mathrm{H}$ content. (a) Representative images of cell cycle; (b) S phase changes; (c) G1 phase changes. (A) normal control; (B) damaged control; (C) DPY-1; (D) DGL-2; (E) DSF-3; (F) DUP-4.

that in the control group (69.1\%) (Figure 4(b)); however, the cell number of G1 phase was markedly increased from $21.4 \%$ of the control group to $50.1 \%$ of the damaged group (Figure 4(c)). After the damaged HK-2 cells were repaired by DSPs, the cell proportion of $S$ phase was significantly increased than the damaged group (Figure 4(b)), whereas the cell proportion of $\mathrm{G} 1$ phase was reduced. In detail, the cell proportion of S phase increased from $40 \%$ of the damaged group to $57.1 \%, 59.3 \%, 60.6 \%$, and $61.4 \%$ of DPY-1, DGL2 , DSF-3, and DUP-4, respectively. That is, the higher the $-\mathrm{OSO}_{3} \mathrm{H}$ content of a polysaccharide, the larger the cell proportion of the $\mathrm{S}$ phase is; thus, the polysaccharide had greater repair effect on the damaged cell.

$\mathrm{Pu}$ et al. [43] showed that the cell proportion of the $\mathrm{S}$ phase $(13.56 \%)$ was obviously reduced, whereas the cell proportion of the G1 phase (85.20\%) was obviously greater compared with normal control cells with $\mathrm{S}$ phase fraction of
$21.82 \%$ and G1 phase fraction of $61.94 \%$ after the WI-38 cells were treated with $\mathrm{H}_{2} \mathrm{O}_{2}$. This result suggested that $\mathrm{H}_{2} \mathrm{O}_{2}$ resulted in significant senescence symptom of WI-38 cell (G1 phase block). However, the cell proportion of G1 phase (36.36\%) was significantly reduced, whereas the cell proportion of $S$ phase $(57.5 \%)$ increased in the Guiqi polysaccharide (GQP) pretreatment group. Ding et al. [44] showed that once the HELF cells were exposed to t-BHP $(400 \mu \mathrm{M})$, the G1 cell population (56.80\%) was significantly higher, whereas the S cell population (39.29\%) was lower compared with the normal control group with G1 and S phase fractions of $33.41 \%$ and $64.37 \%$, correspondingly. Meanwhile, the G1 cell population (44.10\%) was reduced and S cell population increased (53.45\%) after the HELF cells were exposed to TLH-3.

After the normal cells were damaged, cells started self-detection and made the progression of cell cycle slow 


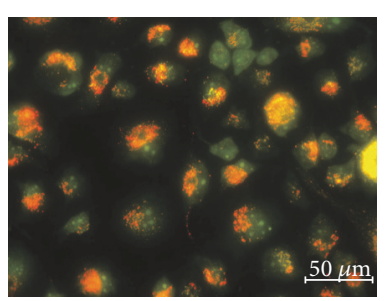

(A)

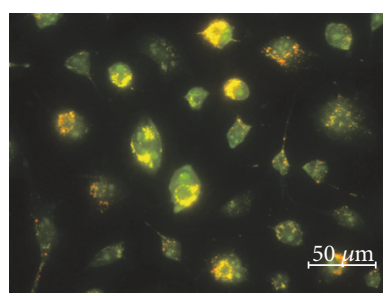

(D)

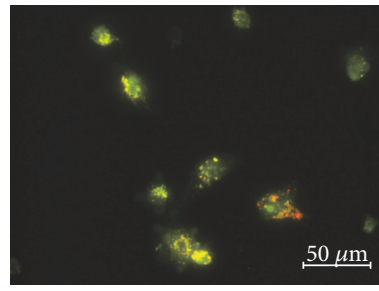

(B)

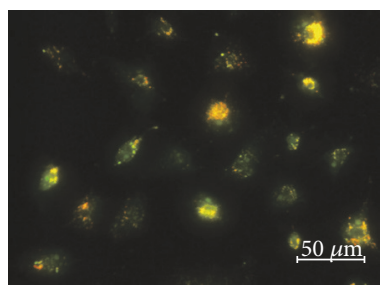

(E)

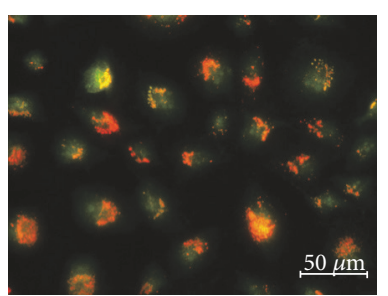

(C)

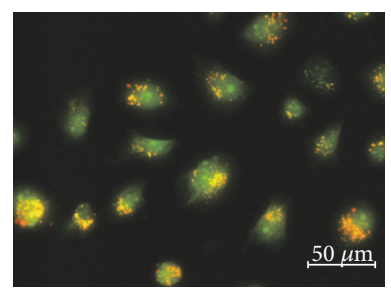

(F)

(a)

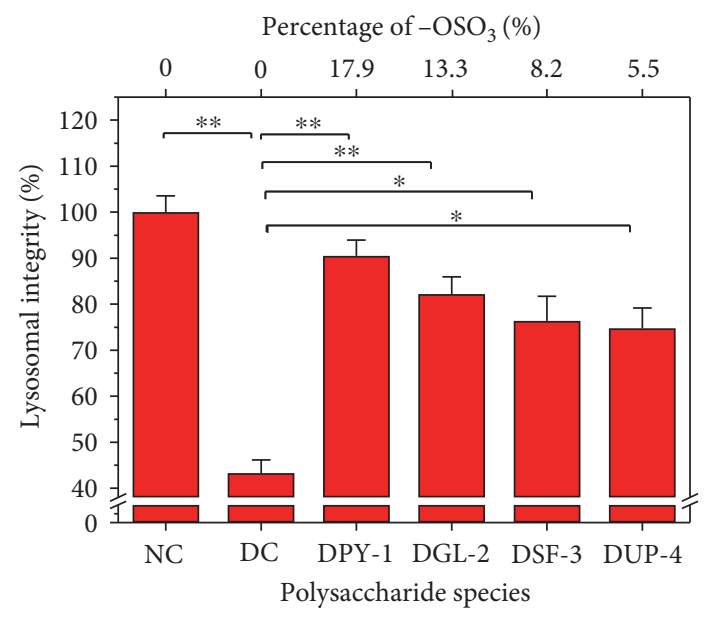

(b)

FIgURE 5: Change of lysosomal integrity after the damaged HK-2 cells were repaired by four DSPs with different $-\mathrm{OSO}_{3} \mathrm{H}$ content. (a) Fluorescence microscope observation; (b) quantitative analysis. Red fluorescence represented unbroken lysosomes; (A) normal control; (B) damaged control; (C) DPY-1; (D) DGL-2; (E) DSF-3; (F) DUP-4. DSP concentration: $60 \mu \mathrm{g} / \mathrm{mL}$; the damage concentration of oxalate: $2.8 \mathrm{mmol} / \mathrm{L}$ injury time: $3 \mathrm{~h}$; repaired time: $12 \mathrm{~h} . * *$ indicates $p<0.01 ; *$ indicates $p<0.05$.

or temporarily blocked to prevent DNA from being replicated and to ensure that the cell genetic material was correct and reproduced accurately [45]. The self-repaired cell can go into the next stage, whereas the unrepaired cell arrested at G0/G1 phase and failed into S phase, which can make cells keep their normal biological function. Therefore, the cell proportion of G0/G1 phase increased, whereas the cell proportion of S phase reduced [44].

3.5. Repair Effect of Polysaccharides on Lysosome. Acridine orange $(\mathrm{AO})$ is a weak base that can go into the lysosome through the cell membrane. AO differentially labels with high and low concentration by forming two polymers or monomers that emit red or green fluorescence. When the integrity of lysosome was destructed, the internal substance of lysosome leaked and orange-red fluorescence reduced [46]. Therefore, the repair degree of lysosome of cells can be determined by measuring the ratio of red and green fluorescence intensities.

The changes of lysosome integrity of HK-2 cell of each group are shown in Figure 5. The lysosome structure was complete, and the superposition of red and green fluorescence showed strong orange-red $(100 \%)$ in normal control cells. When the normal cells were damaged by oxalate, red fluorescence was significantly reduced (43.29\%). However, after the damaged cells were repaired by DSPs, red fluorescence intensity increased with different degrees (Figure 5(b)), and the degree of increase was positively correlated with the $-\mathrm{OSO}_{3} \mathrm{H}$ content of the polysaccharides. The red fluorescence intensity of DPY-1 that had the highest content of $-\mathrm{OSO}_{3} \mathrm{H}(17.9 \%)$ repair group was $90.50 \%$. With the $-\mathrm{OSO}_{3} \mathrm{H}$ content of polysaccharides reduced to $13.3 \%, 8.2 \%$, and $5.5 \%$, the red fluorescence intensity of these repaired groups was $82.22 \%, 76.40 \%$, and $74.75 \%$, 


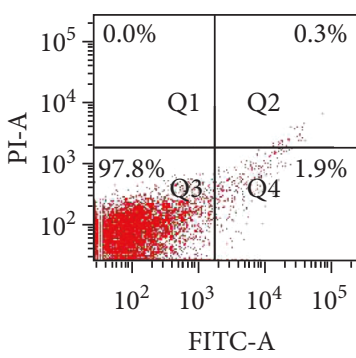

(A)

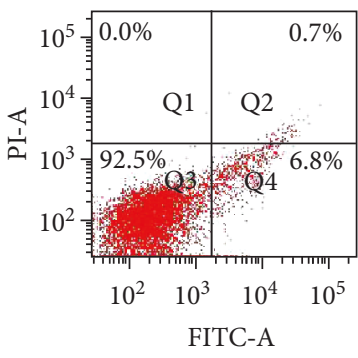

(D)

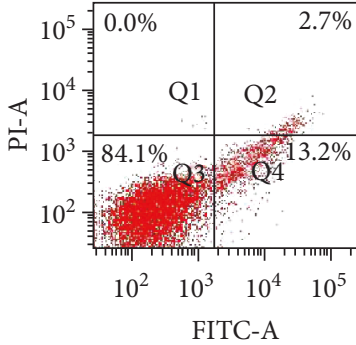

(B)

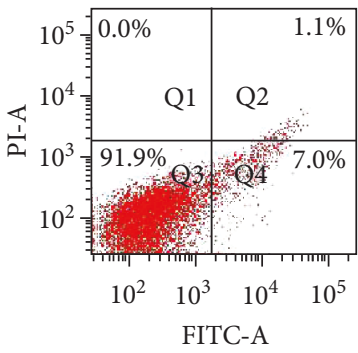

(E)

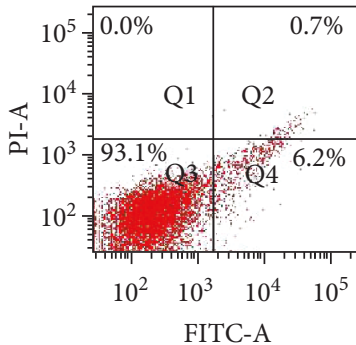

(C)

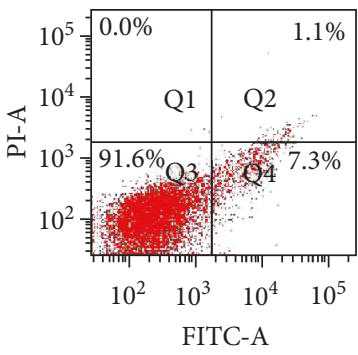

(F)

(a)

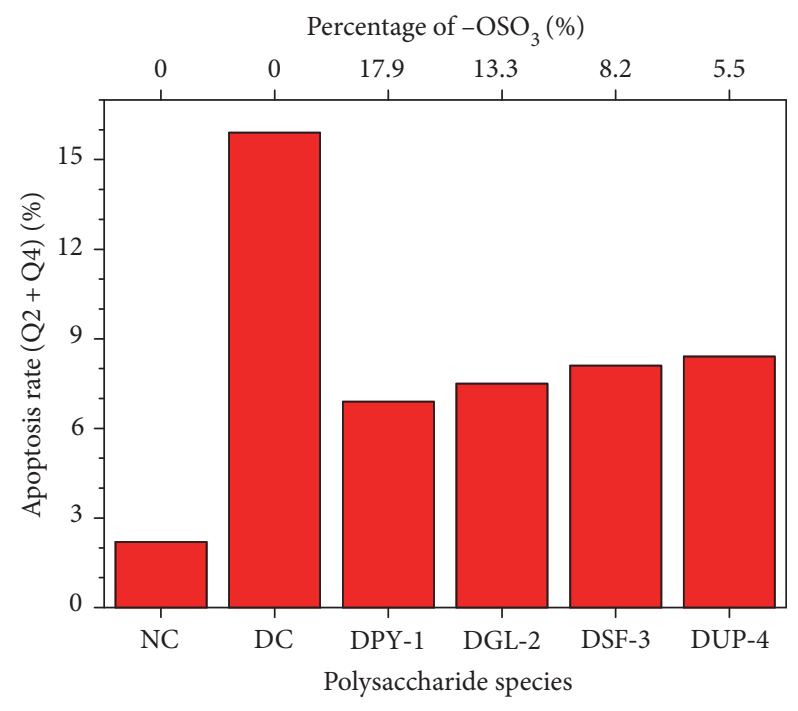

(b)

FIGURE 6: Cell apoptosis detected by flow cytometry after the damaged $\mathrm{HK}-2$ cells were repaired by DSPs with different $-\mathrm{OSO}_{3} \mathrm{H}$ content. (a) Dot plots of cell apoptosis and necrosis; (b) the change of cell apoptosis rate (Q2 + Q4). (A) normal control; (B) damaged control; (C) DPY-1; (D) DGL-2; (E) DSF-3; (F) DUP-4.

respectively. The above results suggested that DSPs had repair effect on lysosomes of cells.

Yue et al. [47] studied the protection effect of Astragalus polysaccharide (APS) on skin fibroblasts and found that the red fluorescence in cells was significantly reduced than in normal control cells after the skin fibroblasts were treated with $0.5 \mathrm{mmol} / \mathrm{L} \mathrm{H}_{2} \mathrm{O}_{2}$ for $30 \mathrm{~min}$. However, the red fluorescence in cells of APS repair group was increased. Rodrigues et al. [48] also studied the protective effect of Aloe vera (AV) extract on UVA-induced $\mathrm{HaCaT}$ lysosomal membrane and found that the lysosomal integrity of AV extract treatment group (82\%) was obviously higher than that in the
UVA-damaged group (45\%), which suggested that lysosome can maintain its intrinsic ability of trapping proton after the $\mathrm{AV}$ was added.

3.6. Effect of Polysaccharide Preprotection on Cell Apoptosis. To assess the nature of crystal-induced cell death, we performed flow cytometric analysis to quantify the apoptotic and necrotic cells using annexin V/PI double staining. Annexin V staining was applied to reveal the surface exposure of phosphatidylserine (apoptosis), whereas PI was applied to reveal the loss of plasma membrane integrity (necrosis). 
The changes in the cell apoptotic rate of each group cell are shown in Figure 6. The total cell apoptotic rate $(\mathrm{Q} 2+\mathrm{Q} 4)$ in the normal control group was very low $(2.2 \%)$, whereas the total cell apoptotic rate in the oxalatedamaged group was significantly increased (15.9\%). After the damaged cells were repaired by different polysaccharides, the apoptotic rate of cells was decreased in different degrees (Figure 6(b)), and the degree of reduction was positively correlated with the content of $-\mathrm{OSO}_{3} \mathrm{H}$ of each polysaccharide. That is, the $-\mathrm{OSO}_{3} \mathrm{H}$ contents of DPY-1, DGL-2, DSF-3, and DUP-4 were 17.9\%, $13.3 \%, 8.2 \%$, and $5.5 \%$, respectively, and the cell apoptotic rates of the repaired groups were $6.9 \%, 7.5 \%, 8.1 \%$, and $8.4 \%$, correspondingly.

Li et al. [39] examined the high glucose-induced ROS production and cell apoptosis of endothelial cells and suggested that the cell apoptotic rate of high glucose treatment group was $20.66 \%$, whereas the cell apoptotic rate reduced to $12.68 \%$ after the cells were pretreated with PSG-1, which indicated that PSG-1 can alleviate cell apoptosis induced by oxidative stress. Similarly, Chowdhury et al. [49] revealed that the bacterial fucoidan can inhibit the $\mathrm{H}_{2} \mathrm{O}_{2}$-induced stress of human lung fibroblasts, and the total cell apoptotic rate of $\mathrm{H}_{2} \mathrm{O}_{2}$-damaged group and polysaccharide repair group was $42.6 \%$ and $10.0 \%$, respectively.

\section{Conclusions}

Four types of DSPs (DPY-1, DGL-2, DSF-3, and DUP-4), with molecular weights of approximately $3700 \mathrm{Da}$ and $-\mathrm{OSO}_{3} \mathrm{H}$ content of $17.9 \%, 13.3 \%, 8.2 \%$, and $5.5 \%$, respectively, were used to repair the HK-2 cells damaged by $2.8 \mathrm{mmol} / \mathrm{L}$ oxalate. With the increase of sulfate group content in DSPs, the scavenging activity of hydroxyl, $\mathrm{DPPH}$, and ABTS radicals and their reducing power were all improved. The sulfate group content is positively related to the antioxidant activity of DSPs. After the damaged HK-2 cells were repaired by $60 \mu \mathrm{g} / \mathrm{mL}$ polysaccharide, LDH release amount reduced, mitochondrial membrane potential improved, cell proportion of G1 phase reduced but cell proportion of S1 phase increased, lysosome integrity improved, and cell apoptotic rate reduced. Moreover, the higher the $-\mathrm{OSO}_{3} \mathrm{H}$ content of DSPs, the more obvious the repair effect of DSPs on various subcellular organelles of damaged HK-2 cells. These DSPs, especially for the polysaccharide with higher $-\mathrm{OSO}_{3} \mathrm{H}$ content, may become potential drugs for the prevention and cure of kidney stones.

\section{Conflicts of Interest}

The authors declare that they have no competing interests.

\section{Acknowledgments}

This work was supported by the National Natural Science Foundation of China (no. 81670644).

\section{References}

[1] D. F. Wei, T. Chen, M. F. Yan et al., "Synthesis, characterization, antioxidant activity and neuroprotective effects of selenium polysaccharide from Radix hedysari," Carbohydrate Polymers, vol. 125, pp. 161-168, 2015.

[2] A. Bhandari, S. Koul, A. Sekhon et al., "Effects of oxalate on HK-2 cells, a line of proximal tubular epithelial cells from normal human kidney," The Journal of Urology, vol. 168, no. 1, pp. 253-259, 2002.

[3] D. D. Zhong, H. K. Wang, M. Liu et al., "Ganoderma lucidum polysaccharide peptide prevents renal ischemia reperfusion injury via counteracting oxidative stress," Scientific Reports, vol. 5, article 16910, 2015.

[4] S. S. Chen, X. F. Gao, Y. G. Sun, C. L. Xu, L. H. Wang, and T. Zhou, "Analysis of HK-2 cells exposed to oxalate and calcium oxalate crystals: proteomic insights into the molecular mechanisms of renal injury and stone formation," Urological Research, vol. 38, no. 1, pp. 7-15, 2010.

[5] R. O. S. Souza, A. M. S. Assreuy, and J. C. Madeira, "Purified polysaccharides of Geoffroea spinosa barks have anticoagulant and antithrombotic activities devoid of hemorrhagic risks," Carbohydrate Polymers, vol. 124, pp. 208-215, 2015.

[6] J. J. Cheng, C. H. Chao, and P. C. Chang, "Studies on anti-inflammatory activity of sulfated polysaccharides from cultivated fungi Antrodia cinnamomea," Food Hydrocolloids, vol. 53, pp. 37-45, 2016.

[7] J. Wang, Q. Zhang, and Z. Zhang, "Antioxidant activity of sulfated polysaccharide fractions extracted from Laminaria japonica," International Journal of Biological Macromolecules, vol. 42, no. 2, pp. 127-132, 2008.

[8] T. I. Imbs, A. V. Skriptsova, and T. N. Zvyagintseva, “Antioxidant activity of fucose-containing sulfated polysaccharides obtained from Fucus evanescens by different extraction methods," Journal of Applied Phycology, vol. 27, no. 1, pp. 545-553, 2015.

[9] Z. S. Wen, L. J. Liu, X. K. OuYang, Y. L. Qu, Y. Chen, and G. F. Ding, "Protective effect of polysaccharides from Sargassum horneri against oxidative stress in RAW264.7 cells," International Journal of Biological Macromolecules, vol. 68, pp. 98106, 2014.

[10] C. Cui, N. S. Cui, P. Wang, S. L. Song, H. Liang, and A. G. Ji, "Sulfated polysaccharide isolated from the sea cucumber Stichopus japonicus against PC12 hypoxia/reoxygenation injury by inhibition of the MAPK signaling pathway," Cellular and Molecular Neurobiology, vol. 35, no. 8, pp. 1081-1092, 2015.

[11] Z. Ye, W. Wang, Q. Yuan et al., "Box-Behnken design for extraction optimization, characterization and in vitro antioxidant activity of Cicer arietinum L. hull polysaccharides," Carbohydrate Polymers, vol. 147, pp. 354-364, 2016.

[12] H. Thevanayagam, S. M. Mohamed, and W. L. Chu, "Assessment of UVB-photoprotective and antioxidative activities of carrageenan in keratinocytes," Journal of Applied Phycology, vol. 26, no. 4, pp. 1813-1821, 2014.

[13] Z. J. Wang, J. H. Xie, L. J. Kan et al., "Sulfated polysaccharides from Cyclocarya paliurus reduce $\mathrm{H}_{2} \mathrm{O}_{2}$-induced oxidative stress in RAW264.7 cells," International Journal of Biological Macromolecules, vol. 80, pp. 410-417, 2015.

[14] P. Bhadja, J.-M. Ouyang, C.-Y. Tan, and K. Yu, "Repair effect of seaweed polysaccharides with different contents of sulfate 
group and molecular weights on damaged HK-2 cells," Polymer, vol. 8, no. 5, p. 188, 2016.

[15] Q. Zhang, N. Li, X. Liu, Z. Zhao, Z. Li, and Z. Xu, "The structure of a sulfated galactan from Porphyra haitanensis and its in vivo antioxidant activity," Carbohydrate Research, vol. 339, no. 1, pp. 105-111, 2004.

[16] M. Guimaraes, A. G. Viana, M. E. R. Duarte, S. D. Ascencio, E. M. Plastino, and M. D. Noseda, "Low-molecular-mass carbohydrates and soluble polysaccharides of green and red morphs of Gracilaria domingensis (Gracilariales, Rhodophyta)," Botanica Marina, vol. 50, no. 5/6, pp. 314-317, 2007.

[17] H. Ye, C. Zhou, W. Li, B. Hu, X. Wang, and X. Zeng, "Structural elucidation of polysaccharide fractions from brown seaweed Sargassum pallidum," Carbohydrate Polymers, vol. 97, no. 2, pp. 659-664, 2013.

[18] A. V. Skriptsova, N. M. Shevchenko, T. N. Zvyagintseva, and T. I. Imbs, "Monthly changes in the content and monosaccharide composition of fucoidan from Undaria pinnatifida (Laminariales, Phaeophyta)," Journal of Applied Phycology, vol. 22, no. 1, pp. 79-86, 2010.

[19] M. N. Garcia-Casal, J. Ramirez, I. Leets, A. C. Pereira, and M. F. Quiroga, "Antioxidant capacity, polyphenol content and iron bioavailability from algae (Ulva sp., Sargassum sp and Porphyra sp.) in human subjects," The British Journal of Nutrition, vol. 101, no. 1, pp. 79-85, 2009.

[20] L. Q. Sun, C. H. Wang, Q. J. Shi, and C. H. Ma, "Preparation of different molecular weight polysaccharides from Porphyridium cruentum and their antioxidant activities," International Journal of Biological Macromolecules, vol. 45, no. 1, pp. 42-47, 2009.

[21] R. Wang, P. Chen, and F. Jia, "Characterization and antioxidant activities of polysaccharides from Panax japonicus C.A. Meyer," Carbohydrate Polymers, vol. 88, no. 4, pp. $1402-$ 1406, 2012.

[22] L. Yang, T. Zhao, and H. Wei, "Carboxymethylation of polysaccharides from Auricularia auricula and their antioxidant activities in vitro," International Journal of Biological Macromolecules, vol. 49, no. 5, pp. 1124-1130, 2011.

[23] K. I. Berker, B. Demirata, and R. Apak, "Determination of total antioxidant capacity of lipophilic and hydrophilic antioxidants in the same solution by using ferric-ferricyanide assay," Food Analytical Methods, vol. 5, no. 5, pp. 11501158, 2012.

[24] F. Yu, X. Li, L. Cai et al., "Achyranthes bidentata polysaccharides induce chondrocyte proliferation via the promotion of the G1/S cell cycle transition," Molecular Medicine Reports, vol. 7, no. 3, pp. 935-940, 2013.

[25] M. E. Guicciardi, M. Leist, and G. J. Gores, "Lysosomes in cell death," Oncogene, vol. 23, no. 16, pp. 2881-2890, 2004.

[26] K. Gao, M. Liu, J. Cao et al., "Protective effects of Lycium barbarum polysaccharide on 6-OHDA-induced apoptosis in PC12 cells through the ROS-NO pathway," Molecules, vol. 20, no. 1, pp. 293-308, 2015.

[27] J. F. Yuan, Z. Q. Zhang, and Z. C. Fan, "Antioxidant effects and cytotoxicity of three purified polysaccharides from Ligusticum chuanxiong Hort," Carbohydrate Polymers, vol. 74, no. 4, pp. 822-827, 2008.

[28] N. A. Panat, D. K. Maurya, and S. S. Ghaskadbi, "Troxerutin, a plant flavonoid, protects cells against oxidative stress-induced cell death through radical scavenging mechanism," Food Chemistry, vol. 194, pp. 32-45, 2016.
[29] H. Song, Q. Zhang, and Z. Zhang, "In vitro antioxidant activity of polysaccharides extracted from Bryopsis plumosa," Carbohydrate Polymers, vol. 80, no. 4, pp. 1057-1061, 2010.

[30] M. Hassas-Roudsari, P. R. Chang, R. B. Pegg, and R. T. Tyler, "Antioxidant capacity of bioactives extracted from canola meal by subcritical water, ethanolic and hot water extraction," Food Chemistry, vol. 114, no. 2, pp. 717-726, 2009.

[31] X. Zhao, G. Yu, N. Yue, and H. Guan, "Effects of lowmolecular-weight polyguluronate sulfate on experimental urolithiasis in rats," Urological Research, vol. 35, no. 6, pp. 301-306, 2007.

[32] V. Tostes, C. A. Martinusso, C. C. C. Werneck, P. A. S. Mourao, and L. R. Cardoso, "Low-molecular-weight dextran sulfate prevents experimental urolithiasis in rats," Clinica Chimica Acta, vol. 341, no. 1-2, pp. 147-155, 2004.

[33] H. Zhang, J.-Q. Wang, S.-P. Nie, Y.-X. Wang, S. W. Cui, and M.-Y. Xie, "Sulfated modification, characterization and property of a water-insoluble polysaccharide from Ganoderma atrum," International Journal of Biological Macromolecules, vol. 79, pp. 248-255, 2015.

[34] S.-Q. Huang, S. Ding, and L. Fan, "Antioxidant activities of five polysaccharides from Inonotus obliquus," International Journal of Biological Macromolecules, vol. 50, no. 5, pp. 1183 1187, 2012.

[35] F. Laffleur, J. Psenner, and W. Suchaoin, "Permeation enhancement via thiolation: in vitro and ex vivo evaluation of hyaluronic acid-cysteine ethyl ester," Journal of Pharmaceutical Sciences, vol. 104, no. 7, pp. 2153-2160, 2015.

[36] Y. Hu, Y. Sheng, M. Yu et al., “Antioxidant activity of Inonotus obliquus polysaccharide and its amelioration for chronic pancreatitis in mice," International Journal of Biological Macromolecules, vol. 87, pp. 348-356, 2016.

[37] C. Y. Zhang, T. Kong, W. H. Wu, and M. B. Lan, “The protection of polysaccharide from the brown seaweed Sargassum graminifolium against ethylene glycol-induced mitochondrial damage," Marine Drugs, vol. 11, no. 3, pp. 870-880, 2013.

[38] C. Cui, N. S. Cui, P. Wang, S. L. Song, H. Liang, and A. G. Ji, "Neuroprotective effect of sulfated polysaccharide isolated from sea cucumber Stichopus japonicus on 6-OHDA-induced death in SH-SY5Y through inhibition of MAPK and NF-kB and activation of PI3K/Akt signaling pathways," Biochemical and Biophysical Research Communications, vol. 470, no. 2, pp. 375-383, 2016.

[39] W. J. Li, S. P. Nie, Y. F. Yao et al., "Ganoderma atrum polysaccharide ameliorates hyperglycemia-induced endothelial cell death via a mitochondria-ROS pathway," Journal of Agricultural and Food Chemistry, vol. 63, no. 37, pp. 8182-8191, 2015.

[40] A. O. Von, N. J. Waterhouse, T. Kuwana, D. D. Newmeyer, and D. R. Green, "The 'harmless' release of cytochrome c," Cell Death and Differentiation, vol. 7, no. 12, pp. 1192 1199, 2000.

[41] Z. H. Geng, L. Huang, M. B. Song, and Y. M. Song, "Cardiovascular effects in vitro of a polysaccharide from Salvia miltiorrhiza," Carbohydrate Polymers, vol. 121, pp. 241-247, 2015.

[42] S. Bleicken, O. Landeta, A. Landajuela, G. Basañez, and A. J. García-Sáez, "Proapoptotic Bax and Bak proteins form stable protein-permeable pores of tunable size," The Journal of Biological Chemistry, vol. 288, no. 46, pp. 33241-33252, 2013.

[43] X. Y. Pu, S. Yu, W. B. Fan, L. Liu, X. L. Ma, and J. Ren, "Guiqi polysaccharide protects the normal human fetal lung fibroblast 
WI-38 cells from $\mathrm{H}_{2} \mathrm{O}_{2}$-induced premature senescence," International Journal of Clinical and Experimental Pathology, vol. 8, no. 5, pp. 4398-4407, 2015.

[44] Q. Y. Ding, D. Yang, W. N. Zhang et al., "Antioxidant and anti-aging activities of the polysaccharide TLH-3 from Tricholoma lobayense," International Journal of Biological Macromolecules, vol. 85, pp. 133-140, 2016.

[45] J. White and S. Dalton, "Cell cycle control of embryonic stem cells," Stem Cell Reviews, vol. 1, no. 2, pp. 131-138, 2005.

[46] F. F. Yu, Z. Y. Chen, B. L. Wang et al., "The role of lysosome in cell death regulation," Tumor Biology, vol. 37, no. 2, pp. 1427-1436, 2016.

[47] X. L. Yue, P. Li, X. Liu et al., "Protective effect of astragalus polysaccharide on mitochondria and lysosome in $\mathrm{H}_{2} \mathrm{O}_{2}$-stressed skin fibroblasts," Chinese Journal of Pathophysiology, vol. 24, no. 4, pp. 777-782, 2008.

[48] D. Rodrigues, A. C. Viotto, R. Checchia et al., "Mechanism of Aloe vera extract protection against UVA: shelter of lysosomal membrane avoids photodamage," Photochemical \& Photobiological Sciences, vol. 15, no. 3, pp. 334-350, 2016.

[49] S. R. Chowdhury, S. Sengupta, S. Biswas et al., "Bacterial fucose-rich polysaccharide stabilizes MAPK mediated Nrf2/ Keap1 signaling by directly scavenging reactive oxygen species during hydrogen peroxide induced apoptosis of human lung fibroblast cells," PloS One, vol. 9, no. 11, article e113663, 2014. 


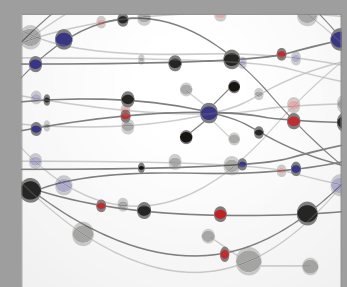

The Scientific World Journal
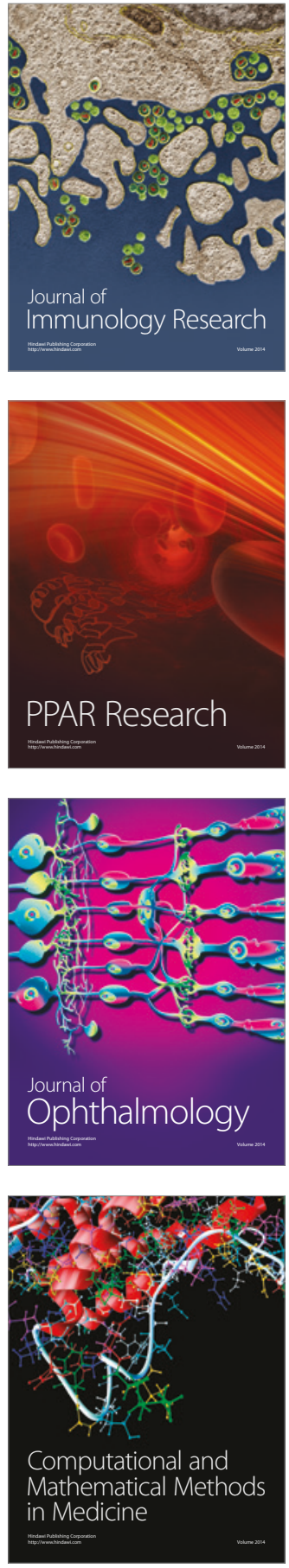

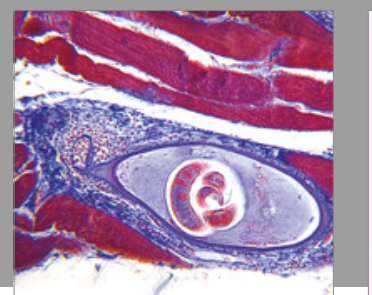

Gastroenterology Research and Practice
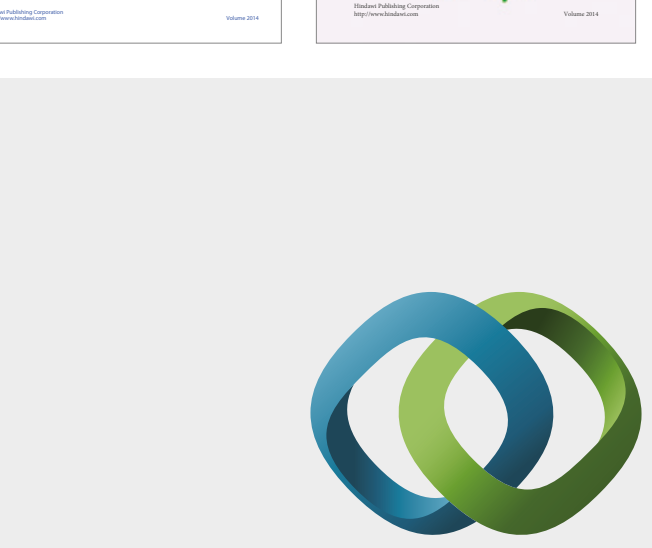

\section{Hindawi}

Submit your manuscripts at

https://www.hindawi.com
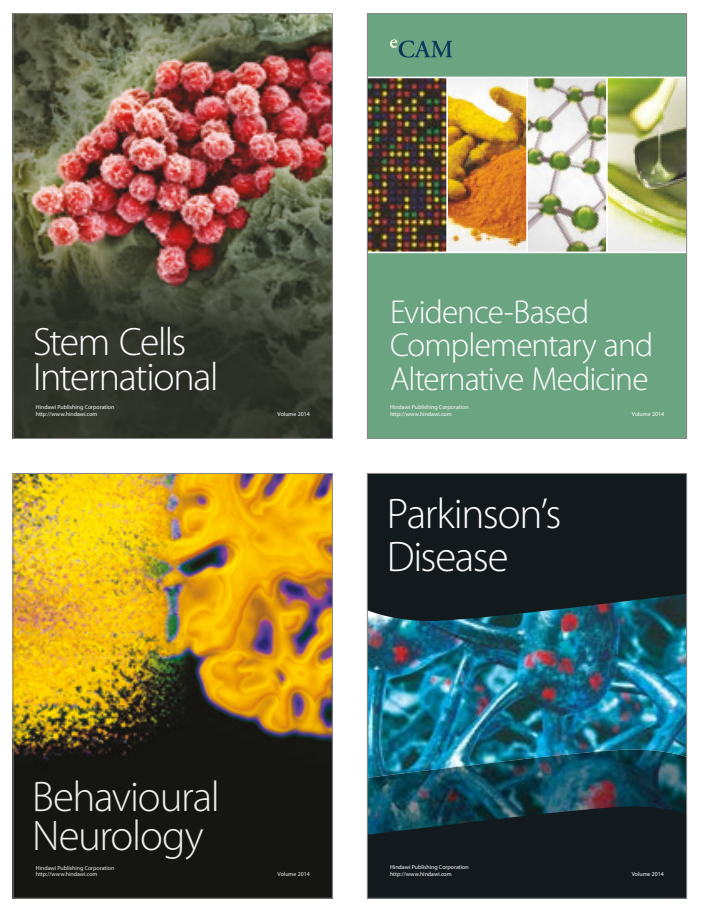
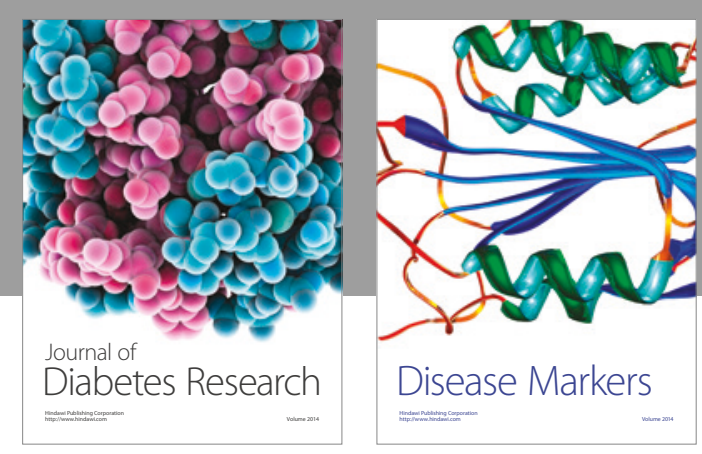

Disease Markers
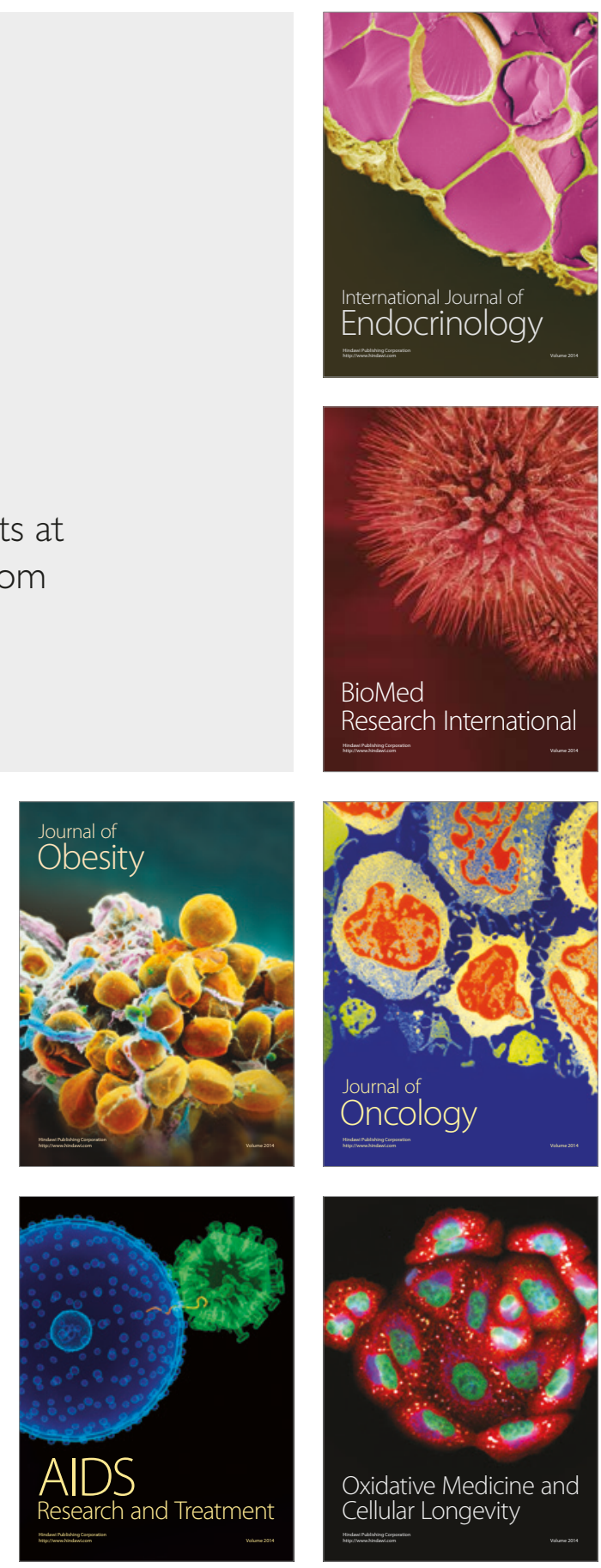